\title{
Introduction: Party-Based Authoritarianism in China
}

Political parties are pivotal institutions, in democratic and authoritarian contexts alike. Almost all seventy-one nondemocracies, in 2015 governing 44 percent of the world population, have parties. In most of these countries at least one party is tightly controlled by the ruling clique, such as United Russia, the United Malays National Organization, and Turkey's Justice and Development Party. ${ }^{1}$ In contrast to other autocratic arrangements, such as military dictatorship and personalistic rule, partybased authoritarianism has proven itself effective in governing modernizing societies and mitigating democratization pressures. ${ }^{2}$ But how do parties contribute to effective authoritarian rule? And what are the origins of effective regime parties? The first question calls for a study of contemporary autocratic governance. The second question takes us back to history. The literature provides answers to both questions, but incomplete ones. The case of the Chinese Communist Party (CCP), which is the focus of this book, promises to change the way we think about the functions and origins of effective authoritarian regime parties.

This book demonstrates that an authoritarian regime party can provide the organizational infrastructure that allows a state to project authority throughout its realm. By implication, the book explains why authoritarian regimes are usually more effective in some parts of their territories than in others: The uneven presence of rank-and-file party members makes an important difference for policy implementation on the ground. The CCP's rank and file empowers the state at the local level, precisely because the overwhelming majority of party members is not in bureaucratic positions, but works outside the government. Chapter 2 develops a new theory of authoritarian regime parties, after which the following two chapters test 
the theory's observable implications for subnational variation in contemporary state-building outcomes, and describe causal mechanisms. To do so, Chapter 3 analyzes the particularly challenging enforcement of the one-child policy, and Chapter 4 turns to the universally relevant statebuilding task of collecting taxes.

The next two chapters turn to the historical origins of local party strength, arguable found in the Second Sino-Japanese War (1939-1945). Chapter 5 shows that Japanese occupation shielded the Communists from persecution by the incumbent Nationalist government and allowed the party to recruit members behind enemy lines, shaping membership patterns at the time of the Communist takeover in 1949. As Chapter 6 demonstrates, early party membership patterns persisted and shape the party's geographic base even today. The last two chapters bridge the temporal gap between the wartime experience and the post-Mao party era by turning to two important episodes in the history of the People's Republic: The Great Leap Forward with its catastrophic famine (1958-1961) in Chapter 7 and the height of the Cultural Revolution turmoil (1967-1969) in Chapter 8. These cases are important, because they caution us that the party has not always and under all circumstances functioned as a faithful implementer of central policies. Yet even under these rather exceptional historical conditions, party membership patterns shaped variation in local policy outcomes.

The remainder of this introduction is organized as follows. After an overview of the argument, I describe the research process that has led to this book. Next, the empirical portion of the introduction provides impressionistic evidence on the functions of the party as a screening, disciplining, and mobilization device. Rank-and-file party members are at the center of this description. Moving from the micro level of the party to the macro level, the chapter then suggests that a map of party membership density captures crucial aspects of governance in the People's Republic. In addition, geographic membership patterns allow analysis of historical continuities and study of the persistence of historical legacies in a parsimonious way. The introduction ends with an overview of the nine chapters. Overall, this introductory portrait of the CCP provides the intuition for a new approach to regime parties, which is the main contribution of this book.

\section{I.I THE GRASSROOTS ORIGINS OF EFFECTIVE AUTHORITARIAN RULE}

The CCP is an exceptionally important political institution of the 20th and 21st centuries on many counts. It has dominated the world's most 
populous country since 1949 . Its leaders are shaping global politics and its organizational branches are present worldwide, some flourishing in the open, others proliferating covertly. The party's decisions may continue to affect peoples' lives around the globe well into the future. Under the auspices of the party, the People's Republic governs a territory that is roughly equal to the United States, but whose diverse population is five times larger. It has maintained effective rule, while many other countries in the world, and much smaller ones, struggle with anarchy and violence. The emergence of a modern and functional Chinese state in the midtwentieth century was certainly not a foregone conclusion, if we think of the widespread violence in the nineteenth century and the five tumultuous decades in the twentieth century between the Boxer Uprising in 1900 and the Civil War ending in 1949. This book argues that in addition to existing explanations pointing to the role of the party in mediating elite conflict, the party's presence at the grassroots level of society must be at the center of explanations for the effectiveness of the Chinese state. The party's rank and file allow the state to penetrate local society; its local branches are capillaries that enable the microcirculation of information. Across policy areas, the rank and file of the single party are key to explaining the lasting effectiveness of the regime.

Uncovering the sources of Chinese state strength is important, first and foremost to understand how 20 percent of the world population is governed today. At the same time the country is not as irrelevant for comparative studies as some analysts have us believe, by putting China into a residual classification category comprising the "almost disappeared" species of "unambiguously nondemocratic regime[s]." 3 Like the majority of authoritarian countries today, China is a party-based authoritarian regime. ${ }^{4}$ The existence of a regime party is an important characteristic of the regime, since strong parties have been identified as a crucial ingredient for authoritarian regime survival. ${ }^{5}$ Yet it is not clear how parties bolster authoritarian regimes, nor how some parties have grown stronger than others. These questions have taken on new urgency now that ideologies have lost some of their force and an instrumental logic has taken center stage. The case of China and the CCP can illuminate the functions and origins of regime parties. To be sure, compared to other regime parties, the CCP may be a particularly sophisticated organization. And yet, notwithstanding differences in the degree of the party's effectiveness, the ways in which party members are deployed in the service of the regime are comparable across nondemocratic regimes. The Chinese case allows investigation of the organizational principles and the causal mechanisms by which party members empower the state. Therefore the case of China 
promises to shine a bright light on the functioning of party-based authoritarianism regimes.

This book goes beyond the conventional wisdom in the literature on authoritarian regimes, according to which regime parties function as patronage-distribution devices, facilitate political deals at the elite level, and serve as democratic concessions. ${ }^{6}$ Moving from the elite to the grassroots level, the book sees the CCP as a sharp authoritarian tool to penetrate the vast and uneven spatial expanse of China's realm. Effective regime parties help rulers elicit accurate information about society beyond the centers of power. I found ample qualitative evidence that the CCP fulfills such a role. For example, an internal paper by the Department of Public Security highlights the unique value of information from local party cells - as opposed to information from the local government apparatus - for suppressing local protests. ${ }^{7}$ For systematic evidence, we can take advantage of the fact that the CCP is unevenly present throughout its territory. Using a definition explained in Section 1.4.1, China's "red provinces" with high party membership density look very different from "pink provinces" where the party is less present:

- In red areas, local governments were more effective at monitoring the implementation of the one-child policy. While bureaucrats tend to be able to achieve the goal of reducing the number of births, it is much harder to avoid the severe side effect of gender-selective abortions, which is more successfully achieved in red localities.

- In red areas, local governments extract more taxes. Party members help local governments overcome asymmetric information problems that plague other tax systems at the grassroots level. They also coerce and convince fellow citizens to pay their dues - even if at the same time party members themselves have the privilege of being more lightly taxed.

In short, the book analyzes the party's role in the information architecture of the authoritarian state, with implications for state capacity and ultimately for regime durability as well.

The differences between "red provinces" and "pink provinces" were at least as tangible during the first decades of the People's Republic as they are now. However, probing the limits of the straightforward argument that the party functions as faithful implementer of central policy, one finds cases when the presence of many party members on the ground did not help to advance the central leadership's policy agenda. 
- In the decade after the Communist takeover, some local leaders were still locally connected, deeply committed, and independently thinking revolutionaries. They realized the danger inherent in Mao's Great Leap policies and were willing to drag their feet. Although such leaders were a minority, one would typically find them in areas with the most combatant party members, namely the places most violently contested between the CCP and the Japanese Imperial Army. This small minority of remnant revolutionaries resisted communization policies and alleviated the famine, but this minority of the most committed could not prevent the death of tens of millions of Chinese.

- Party members were also not enthusiastic when their own privileges were at stake during the great turmoil of the Cultural Revolution. When Mao Zedong called on citizens to attack the institutions of the party state, formal party hierarchies ceased to function. Rather than promoting the turmoil, party membership networks contained it. Even when joining in the fray, party members acted in a way that facilitated a quick return of order.

Refining the simple party-as-implementer hypothesis, in these two historical instances the party appears, from the perspective of central leaders, as a double-edged sword. On the one hand, strong party networks slowed down policy implementation, but with the benefit of hindsight we know that it actually helped to achieve larger state-building goals: Great Leap Forward policies happened to be a devastating scheme, so that episodes of resistance now make the party seem like a self-corrective device. Similarly, the party's role in the Cultural Revolution suggests that the institution is self-protective, and thereby ultimately advances the party state's resilience.

Moving back the causal chain, as indicated by the arrows in Figure 1.1, the next goal is to find out why the party is so much more present in some areas of its realm than in others. While the party was founded in 1921, it was only under China's partial occupation by the Japanese army from 1937 to 1945 that party organizers were able to set up a lasting, local structure. Japanese occupation jump-started the party by giving the Communist Party respite from government persecution and by letting it mobilize citizens on patriotic (or xenophobic) anti-Japanese grounds. As my analysis shows, areas formerly occupied by Japan even today tend to remain the party state's power base. Japan's intrusion into the East Asian mainland was a critical juncture in modern Chinese history. 


\section{Generic}

argument

Historical contingencies

(1937-1949)

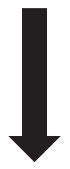

Transmission

(1949-2015)

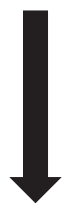

State-building outcomes

(1958-2015)
China-specific argument

Local patterns of the

Sino-Japanese War (1937-1945)

and Civil War (1945-1949)

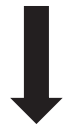

Lasting membership patterns, because Leninist party carries out path-dependent recruitment

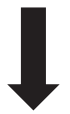

Geographic patterns of

- Severity of Great Leap Forward famine (1958-1961)

- Degree of Cultural Revolution turmoil (1966-1976)

- Enforcement of the one-child policy (1978-2015)

- Fiscal extraction (ongoing)

FIGURE I.I Outline of the argument: history, transmission, contemporary effects

Why can the party not turn all of China from pink to red? In other words, why do formerly Japanese-occupied areas still tend to be red? The overlap can be only very partially explained by Japanese occupiers and CCP leaders sharing similar strategic interests in governing certain localities. More importantly, path-dependent continuities result in regional patterns of CCP membership that reflect contingencies of the Sino-Japanese War from seven decades ago. Since Japan occupied only some parts of the Chinese territory, we can isolate the lasting effect of the Sino-Japanese War on membership patterns today.

Yet one cannot point to historical continuities after the critical juncture of Japanese occupation without at the same time noticing a gradual evolution away from these initial patterns. Following Kathleen Thelen's call to take slow-moving process as seriously as critical junctures, the analysis scrutinizes the evolution of party membership patterns over time. ${ }^{8}$ To do so, this book applies formal models of economic growth and convergence to the dynamics of local party membership, pointing to the time periods when membership patterns took new shape and assessing the overall 
"half-life of history": how long it takes for the initial differences in party penetration to be cut in half. The result shows that the effect of Japanese occupation on party strength disappears over time, but only at a very slow rate. The methodological approach, albeit developed with the example of the CCP in mind, could be applied to all membership-based organizations, as well as other evolutionary processes of political convergence.

The book also argues that different types of recruits self-selected into party membership during this period, depending on the locality where they joined the party. Members recruited in the party's safe havens tended to be more opportunistic than members recruited in dangerous proximity to the Japanese occupiers. To identify safe havens and embattled areas, the book uses fine-grained information from maps and reports, found in Japanese archives, as well as in party organization histories. My claim is that one decade after the Japanese occupiers had left, the more opportunistic recruits readily complied with Mao's communization policies, even as their disastrous consequences became increasingly clear. While overall the CСP failed to stop the Great Leap Famine, in the areas which had experienced the most intense anti-Japanese struggle, local CCP leaders attempted to resist the central policy and thereby dampened its impact. With the aid of fine-grained mortality statistics, I find fewer famine deaths in formerly embattled areas, even after controlling for socio-economic differences.

There are multiple reasons why early party membership patterns persist (see Chapter 6). One important reason is that apparently the Organization Department does not place a priority on evening out the organizational reach of the party. Strategically, it might be advantageous to recruit precisely in the places where the party is most present already, because it is least costly to gather information about new members. In other words, party organizers have good reason to go after the low-hanging fruit first. In addition, there might be certain beliefs and governance techniques inherited from the imperial past, which continue to inform Chinese statecraft. Imperial era techniques, perfected over centuries, remain uniquely suited for a central authority to govern a large and diverse continent in an autocratic fashion and therefore contribute to regime resilience. Whereas other states see uniform control and nationwide standardization as top priorities, China's administrators are unusual in making conscious and explicit choices of how to deploy power resources and enforce authority selectively. For instance, 300 years ago the Chinese imperial court used a standardized coding system to assess governance challenges in its territory and deploy state resources accordingly. While imperial-era 
governance techniques certainly shape the assumptions that underlie strategic choices today, they are outside the scope of this book. ${ }^{9}$

\section{I.2 FROM FIELD OBSERVATIONS TO A THEORY OF THE PARTY}

This book has its empirical roots in China's second-tier cities and hinterland counties. First inspecting politics on-site, talking to elites and citizens, I extensively used the investigative mode of political science before turning to the tools of statistical inference and to the formal logic of models. Moving between localities, whether as a field researcher or a business person, one is bound to encounter the uneven reach of the Chinese state. ${ }^{10}$ When I first visited the four counties in Shandong that served as my initial research sites, I was struck by how each of these local governments had its own interpretation of a policy called New Socialist Countryside Construction 社會主義新農村建設. Since this policy created visible outcomes, including brick-and-mortar structures, the differences caught the eye. In one county, the government was content to experiment with garbage collection and provide the villagers with fresh paint - choosing a dark-yellowish color, apparently in an attempt to maximize its lifetime. In another county, driven by an ambitious, prefectural party secretary parachuted in from Beijing, the government took a more activist stance, deployed Great Leap Forward rhetoric reminiscent of Maoist times, bulldozed villages, and asked villagers to buy newly built apartments, whose price was not affordable to most locals and whose location and layout had obvious disadvantages. Yet another county had employed researchers from the urban planning department of one of China's leading universities to conduct surveys and select villages, whose villagers would most welcome - or least oppose - resettlement programs. ${ }^{11}$ Finally, another county avoided implementation altogether, setting up one fake construction site to show to upper-level cadres (and one foreign Ph.D. student) eager to see New Socialist Countryside Construction. Although this particular policy was too multifaceted to be easily amenable to comparison, ${ }^{12}$ it motivated the question of what makes the state strong, maybe even strong-armed, in some places, but more soft-spoken in others. Researching this question let me discover the role of the party.

Nothing in the political science literature had prepared me to look for an answer related to party organization at the grassroots. The party used to be of utmost interest to social scientists in the 1960s and 1970s, but is receiving little social scientific interest today. ${ }^{13}$ Informed by Lily Tsai's work, ${ }^{14}$ I expected local society to play a decisive role in shaping local state-society relations, with homegrown societal organizations 
giving locals better bargaining positions in some places than in others. Yet it became clear to me that local society was facing ${ }^{15}$ different local manifestations of the Chinese state. Moreover, what struck me was the varying nature of local party presence, to which scholars have paid only minimal attention. ${ }^{16}$ In the case of the Soviet Union, scholars only became fully aware of the uneven effectiveness of the party shortly before its downfall. ${ }^{17}$ More generally, compared to scholarship from the middle of last century ${ }^{18}$ researchers today pay little attention to the party and its grassroots, instead oftentimes studying the party state as if it were a relatively ordinary bureaucracy. ${ }^{19}$ As this book demonstrates, it is a fruitful enterprise to explore the variation in the party's presence across the country and its varying impact on the lives of ordinary people.

As with the existing literature, conversations with practitioners also did not immediately point to the importance of the party to explain subnational variation, albeit for different reasons. In conversation with local officials, I occasionally noticed their genuine surprise when I told them about the different ways in which other nearby counties implemented recent directives. But all in all the differences are too enormous to go unnoticed by practitioners. Instead, many Chinese officials are uncomfortable discussing the fundamental heterogeneity of the Chinese state and prefer to hold up the myth of a uniform state. In my first dozen interviews in China, a most frequent expression was Cha-bu-duo 差不多: There is almost no difference! Question to the fiscal department: "Is your county more or less effective than your neighboring counties at mobilizing fees for public projects?" Answer: "Cha-bu-duo." Question to the general office: "Which county in this prefecture is the strictest enforcer of the one-child-policy?" Answer: "Cha-bu-duo." Question to the history office: "During the Cultural Revolution, was your county hit as much as the neighboring counties?" Answer: "Cha-bu-duo." Acknowledging the uneven presence of party members is particularly unwelcome and goes against the propaganda message of China's homogeneity. Asking about differences in the administrative setup is an unwelcome form of splittism: "Has the foreigner come to doubt the unity of China?" With enhanced questioning techniques, one can advance beyond the chabu-duo response: Why has party membership grown so quickly in your county, compared to all the other counties in Shandong? One is then confronted with answers related to leadership, historical and contemporary. The perceptions of local cadres could be summarized as a call to "bring the leader back in," the relevant leader in this case being the series of party secretaries that happened to run the locality over time. ${ }^{20}$ Other answers, including by Chinese academics, have a flavor of reverse modernization 
theory: Instead of political development creating a tendency toward political pluralism at odds with the authoritarian state, the authoritarian state may be at its best in most developed places.

What implications do local state-building outcomes have for the overall "strength" of the Chinese state? It is important to understand the opportunities and the limits of the subnational-comparative approach to study a whole country's state strength, whether carried out as field research or data analysis. First, the approach does not provide much analytic mileage if subnational outcomes are very similar and leave little room for comparison. Fortunately, a lack of diversity certainly does not pose any major concern in the case of China. The effects of corruption, nationalism, or Confucian culture are all studied at a subnational level. Second, specific to the study of the state, a more serious problem arises because the state is not so easily disaggregated into its component parts. Something is missing if we conceptualize Chinese state strength as the "product" of local government strengths. A more precise analytic breakdown of state strength to the county level might be written as

$$
\text { State Strength }=\underbrace{\prod_{0}^{2,900} \text { strength in county } d x}_{1 \text { st multiplier }} \times \underbrace{\text { strength at center }}_{2 \text { st multiplier }}
$$

Factoring in the strength of the state as it is observed in each of China's roughly 2,900 county-level jurisdictions, the first multiplier integrates strength across the realm. The second multiplier captures strength at the center. The equation expresses the fact that Chinese state strength is a combination of strength out in the realm and strength at the center. If local governments had a good grip on society, but elite conflict was rocking the boat, one would not consider the Chinese state to be strong. Inversely, if politics at the core of the state in Zhongnanhai were orderly, but the realm was in chaos, this would also not be a strong state. Just as order at the center promotes order at the local level, so also does order at the local level promote order at the center. This book explores the first multiplier and follows a subnational comparative method by asking why the Chinese state is stronger in some places than in others.

\section{I.3 MICRO LEVEL: RANK-AND-FILE PARTY MEMBERS}

The power of the Chinese government rests on a well-organized, nationwide party network. Western eyes, accustomed to the sight of crumbling 
Communist parties in the Soviet Union and Eastern Europe two decades ago, tend to see the CCP as an anachronistic leftover from the past. Systemic corruption among its leaders further contributes to the impression that the party is doomed to what Lü Xiaobo calls "organizational involution." 21 If Chinese citizens themselves perceive the party as thoroughly corrupt, so the argument goes, the CCP's legitimacy and with it the regime's authority will evaporate before long. As David Shambaugh demonstrates, views of the party as an outdated component of an ossified Leninist system are misleading. While the party undergoes decay and atrophy in some areas, it is also reinventing and adapting itself in others. ${ }^{22}$ Corruption is bound to occur where so much power is concentrated in the hands of a few local officials. In a setting where classic Communist ideology is largely passé and most party members join for nonidealist reasons, ${ }^{23}$ the vested interests that come with privileges are part of the glue that holds the regime together, even if at the same time they undermine the party's remaining legitimacy. Moreover, the overwhelming majority of party members are nonelite rank and file party members, with few opportunities to sell privileges. ${ }^{24}$ At the end of the day, the CCP remains an indispensable instrument of the regime. ${ }^{25}$

The lifeblood of the party are its 88 million members (as of the end of 2014). This corresponds to "only" 6 percent of the population, ${ }^{26}$ but translates into a substantial presence of the party in society. Three reasons stand out: First, multiple party memberships in the same household are rare. In rural areas, among all households with a party connection, more than 90 percent contain exactly one party member, whereas less than 10 percent contain multiple party members. ${ }^{27}$ As a result of such dispersion, 23 percent of all rural households have a party connection, even if the household is narrowly defined as a living community of four people on average. Second, members are dispersed through various strata of society. Party cells exist in villages, urban residential communities, companies, government agencies, and schools. In each of these settings, over the past twenty or thirty years, party cells have developed increasingly specialized goals, functions, and operating procedures, keeping up with the challenges of a quickly differentiating society. ${ }^{28}$ Organizers make sure that the party is present where it matters most. Recently, tailor-made forms of party organizations have been set up within NGOs of a certain size. ${ }^{29}$ Third, tweaking a Leninist apparatus to serve a postCommunist government, membership in the party functions as an effective screening device to identify politically loyal citizens, who are put to work in the interest of the elite. The remainder of the section describes the 
organizational methods that help the CCP to secure its dominant presence in society.

\subsubsection{The Party as Screening Device}

For ruling elites everywhere, it is vitally important to identify individuals prepared to support their regime, especially among young people who have no political record and are amid a large pool with many potential protesters. But how to distinguish between "reliable" and "less reliable" groups of people? One important function of the party is to serve as a screening device, helping to assess individuals' readiness to play by the rules of the system. In game-theoretic language, to elicit information about political attitudes, ruling elites design a "strategic game" that reveals otherwise hidden characteristics. Confronting someone with the choice to enter the party or not is such a game. For politically conscious Chinese, as for many people in formerly Communist countries, this moment of choice is a memorable one. Many would recount this confrontation to intimate friends for the rest of their lives. The reliability of the "strategic game" is further enhanced by plain investigations concerning the background of potential party members.

Nowadays, the choice may be less ideological. To the extent that ideology does continue to play a role for some party members, it is nationalist sentiments, not Communist ideals, that motivate people. Many ordinary Chinese are convinced that joining the party is all about privileges, as countless variations of anti-party curses suggest. Comparing corrupt party members to insatiable termites eating up the trees all around them is one of the less vulgar metaphors. Even the party members themselves often downplay their ideological commitment. On the Internet, one blogger asked: "Question to party members: Were you sincere when you took your party oath?" We cannot verify whether the respondents were actually party members, but the answers are similar to those I heard in countless conversations, and give me confidence that people curse the party not only during encounters with foreigners:

- If there are no benefits, who would join the party?

- It's all about career and renminbi. Conscience falls flat on the face. (Literally: Conscience turns into a dung-eating dog.)

- Basically, everyone is currying favors. When in a factory there is downsizing and someone is a party member, then it's no longer about economies of scale, but it's all about scale without economics. 
- At the time of taking the oath, I was sincere. But now, actually, .. sigh ...

- Yes, generally that's how everyone puts it. Sincere ... haha, I refuse to believe.

- It was just a task to be completed. ${ }^{30}$

Blog entries such as these indicate that, in many social settings including universities, party membership is not a source of pride. In Chinese universities, especially elite universities with very high proportions of party members, we often hear students downplaying the political significance of party membership: "The academically most outstanding students are offered party membership and naturally do not refuse it." It would be naive to think of party membership among students as nothing more than an academic prize. The undeniable fact is that some outstanding students are not party members. Some students refuse or even revoke party membership. More typically, students are never offered party membership, if their critical mindset is known to their educators. What joining the party signifies is readiness to compromise with the state. Precisely if there is little inner commitment to the party, let alone to ideas of Communism, the act of joining the party reveals that a person is a pragmatist, joining the party for material benefits, better career prospects, or at least to continue a harmonious relationship with one's superior. The new recruit will have to be at least outwardly loyal to the party-state, submitting to party discipline.

The procedure for joining the party has become increasingly elaborate and standardized. During the Cultural Revolution, shortcuts existed to quickly admit new party members without fulfilling the minimum procedural requirements, as stipulated by the party constitution. When the political winds turned and party leaders sought to purge the most troublesome rebels, quick admittance to the party was denounced as "flying over the ocean." To protect the hierarchical integrity of the party, formally correct admittance procedures were emphasized more than ever before. Since then, with each edition of work manuals for basic-level party cadres, the description of how a person is to join the party becomes lengthier and more specific. According to the statutes of the CCP, a person becomes a party member after submitting an application letter; two full party members must support the application, guaranteeing the political integrity of the applicant. Nowadays, the application usually is preceded by two stages. First, a person enters a category called "activist with ambition to join the party." At that stage, two party members are designated to instruct the person about the orthodox party line, and the activist is required to 
participate in training programs at the local party school. Second, the person turns into a "party development target," during which stage he comes under even closer scrutiny. ${ }^{31}$ The process from writing the application to entering the party takes years. As of 2015, standard manuals list as many as thirty stages to full membership, characterized by red tape, forms to be filled out, and reporting up and down the hierarchy. ${ }^{32}$

The most intimidating step in the process of joining the party is an interview with a group of party members, including cadres from the Organization Department. Reading the minutes of such interrogations, ${ }^{33}$ one has the impression of a not-so-subtle form of hazing, where the aspiring member is slowly pushed into a corner to be humiliated. After the unpleasant experience of political interrogation, the process of joining the party concludes more ceremoniously, when the new party member is sworn in at a highly ritualized meeting, most of the time along with others. After several speeches, the new party members take a solemn loyalty oath before the party flag, the central stage prop of this event. The party leaders read out the oath sentence by sentence, and the new party members repeat in chorus. When the time comes to insert the individual's name into the oath formula, at least when there are not too many participants, the chorus stops and each person says his own name, going from left to right. The ceremony ends as it began, with the national anthem. The twin purpose of the meeting is to make tangible the political elite status associated with party membership, as well as to stand as a friendly reminder that the mutual deal between the party and the individual requires first and foremost the public display of political loyalty from the new party member. The power of the party is built on the political loyalty of its members.

\subsubsection{The Party as Disciplining Device}

Strengthening party discipline has been the hallmark of Xi Jinping's tenure as General Secretary of the CCP since 2012. Preparing for more turbulent times, he urges party members to uphold discipline and believes in turning up the heat on them:

If a furnace is not heated up for a long time, or if it is heated up but not at a sufficient temperature, then it could not produce steel. In real life, if inner-party life slackens for one inch, the party troops will scatter by one inch. ${ }^{34}$

The anti-corruption campaign, in addition to fighting corruption and eliminating political enemies, is an effective tool to intimidate party members into obedience. Like historical campaigns of the Mao era, it serves 
to keep up "the politicization, the principled stance and the combative nature of inner party life." 35

The anti-corruption campaign is only one particularly obvious manifestation of a broader process that attempts to transform the party into a more smoothly functioning Leninist hierarchy. Often described as a "return" to a better past, in fact it is not clear whether there ever was a long period of what leaders might imagine to be "perfect" party discipline. So far, an imperfect level of party discipline has been enough to effectively govern the country. Prior to the Communist takeover, local party cells had much autonomy. During the 1950 s, a series of violent campaigns combated a perceived lack of party discipline. The Cultural Revolution in the 1960s and 1970s saw an utter breakdown of party hierarchies, and the 1980s was the most liberal era of the People's Republic. Distinguishing between political discipline and economic corruption, which thrived against the backdrop of China's economic rise, from a historical perspective, political discipline in recent decades has been strong and is reaching an all-time high under Xi's leadership.

Even when there is no campaign time, by joining the party, a person submits to a host of disciplining devices. The formal escalation ladder, prescribed in article 10 of "CCP Regulations on Disciplinary Actions" 中國共産黨紀律處分條例, progresses from warning, to revoking a party member's legal immunity, and, in the worst cases, to expulsion. In ordinary circumstances, very few people are expelled from the party. During 2010, only 0.04 percent exited the party for reasons other than death. Even this tiny number is an overestimate, because it also includes people who left the party of their own volition. There are no regular procedures for leaving the party. Some achieve it by leaving the country and by ceasing to pay their dues. One "party member turned opposition" said that she was informed via prison loudspeaker about her exclusion from the party. ${ }^{36}$ Only in times of great political upheaval does the threat of expulsion become a tangible possibility. In 1989, the year of the Tian'anmen Massacre, 0.4 percent exited the party under irregular circumstances. ${ }^{37}$ The concern of most party members is not expulsion.

Since the Eighteenth Party Congress, the small minority of party members who work in the party state bureaucracy is extraordinarily concerned about disciplinary action, as the prominent display of related books on the shelves of local bookstores reflect. ${ }^{38}$ But despite spectacular expulsions of party leaders at all levels of the government, expulsions of rank-and-file party members still remain rare exceptions. For the everyday disciplining of the membership, to make sure that party members show up to the 
weekly party cell meetings, that they actively participate in party projects, and that they do not post inappropriate messages on the Internet, a reprimand from the party secretary is the most tangible threat. If a party member is invited "to drink a cup of tea with the party secretary," this is usually a euphemism for receiving a small yet dreaded reprimand. It may involve public shaming, as well as an entry into one's record, which is perceived to diminish career opportunities for the rest of one's life, accompanying a person to the grave and beyond.

Xi Jinping has revived Maoist practices of public critique with selfcritique 批評與自我批評. Reminiscent of the Cultural Revolution, party propagandists work hard to dispel the notion that such forms of criticism are a dangerously anachronistic "leftist mistake." 39 Some local party organizations still preferred to refer to the procedures by more innocuous terms like public summary and self-summary 總結與自我總結 and in practice often tended to carry out public praise and self-praise meetings instead. ${ }^{40}$ To prevent too soft and self-indulgent approaches by local party organizations, the central government decided to let a (carefully chosen) public participate. ${ }^{41}$ Even when measures to discipline the party are toned down and softer approaches are chosen by local party organizations, the relentless onslaught of campaigns - including one to hand-copy the party constitution - inspires anxiety among local cadres and rank-and-file alike.

Thought reports are one of the party's evergreens: as a dreaded and effective disciplining device, they have survived the party's many twists and turns and were part of the standard repertoire even at the most liberal moments of the reform era. Aspiring party members must write such reports. Seven months into one's party membership, another report is due. Later on, special occasions such as a political campaign or a trip abroad involve reporting requirements. ${ }^{42}$ If a thought report is required after some misstep, it becomes a self-criticism reminiscent of the kind prevalent during the Mao era. Under certain circumstances, a party member becomes subject to a comprehensive evaluation, an occasion at which members of the same party cell - consisting of between fewer than ten to a couple of dozen members - must evaluate the person. Evaluations include achievements at the workplace, political loyalty, level of altruism, and even intimate questions on personal lifestyle. There are not only sticks, but also carrots. If one's relation with the party is going well, it may be a pleasure to receive the party secretary's visit on occasions such as the death of one's relative or one's birthday, sometimes with a nice gift as well. ${ }^{43}$ 


\subsubsection{The Party as Mobilizing Device}

Party members also serve as a dependable workforce to carry out specific projects on the ground. During the outbreak of the SARS pandemic in 2002, the government stipulated severe domestic travel restrictions. It is doubtful whether enforcement would have been as effective as it was without a party campaign taking place in the background. Similarly, the Beijing Olympics of 2008 prompted another highly visible campaign that impressed international visitors, and where party organizations played a formidable role to mobilize individuals as volunteers. This kind of partyorganized civic activism is by no means limited to extraordinary events, but is an everyday occurrence. In the summer of 2012, on Sundays, an impressive army of volunteers, old and young, flooded the streets of major cities, helping with traffic control at busy intersections. They were sacrificing two hours of their Sunday spare time, suffering from heat and dust. Their flashy uniforms praised the altruist virtues of the model soldier Lei Feng, who had sacrificed his life in a failed attempt to help a truck backing up. The volunteers were (oftentimes new) party members mobilized by their party cells. ${ }^{44}$ This campaign may or may not improve traffic safety. It certainly is a bonding experience and socializes party members into a habit of calling their fellow citizens to order. One nationwide campaign asked party member volunteers to "sacrifice their precious blood" in a blood donation drive.

Campaigns including ideological propaganda movements, as well as practical campaigns such as in the health sector, belong to the standard repertoire of Chinese political culture and are critically important for the regime's effectiveness: "Mao's techniques of mass mobilization, born in revolutionary struggle, but adapted to the tasks of post-revolutionary rule, lie at the heart of Chinese exceptionalism," as Elizabeth J. Perry writes. ${ }^{45}$ The party is indispensable for campaign-style governance: It is party members who first advertise new mass movements, for example, by writing propaganda slogans on walls or hanging up red banners. "Enthusiastic" party members create the initial momentum needed to get campaigns off the ground. Only through its members can the party achieve the minimum level of coordination necessary for mass mobilization to function properly and fulfill its purpose.

Party cells engage in a broad spectrum of more or less political activities. The minutes of a party cell meeting at an institution of higher education give a flavor of the range of possibilities. To generate ideas for the 
party cell's new activities, members were asked to brainstorm and made the following suggestions:

Ma: Let's support the school promoting the new energy saving base, encourage some outstanding students to participate in the construction and development of the base.

Ceng: In Xi'an, some citizens and students were recently taken advantage of by people with ulterior motives, they took to the streets and demonstrated. We should start a campaign, explaining to students that unorganized and illegal demonstrations hurt them, the government and the nation and that they should love their country.

Chen: We should link up with the other party cells of this school for some common activities, progressing all together.

Wang: Even if supermarkets are no longer allowed to give out plastic bags for free, many people, when they go shopping, still buy plastic bags, not thinking of the environmental damage. We should go and investigate the problem.

Ma: To make everyone more familiar with the party's thought, line and policy, we can distribute red propaganda fliers, so that everyone understands better "red thinking."

Zhang: The situation in the quiet study room is terrible. Many students put their bags down in the early morning and block up all the space, let's investigate!

Liu: For everyone to fully grasp emotionally what the party's thought, line and policy is, we can organize a tour to the nearby East Big Village and listen to people 80 years and older, reporting about the situation around the time of liberation, and how things have changed over time.

Shi: Our Institute for Astronomy has a Astronomical Science Popularization Team, we can build on our school's specialty and help popularize astronomy, offering courses and giving lectures.

Yang: These days in many places throughout the country many people blindly join in demonstrations, with a very negative effect. We can go around the school collecting signatures, appealing to everyone's patriotism and make everyone understand the damage that comes with such blindness.

Jiang: Close to our school, there is the tomb of the patriotic anti-Japanese military leader Zhang Lingfu, we can organize everyone to go visit the tomb, to promote everyone's patriotic sentiment.

Su: Our school is located at the foot of the Qinling mountains, minerals are abundant around here. We can go investigate the national resources.

Bai: Our party cell meetings are missing some dynamism, everyone must be more animated, we can organize a few discussion sessions, debating each other, hopefully this can have an impact on our thinking, like a spark. ${ }^{46}$

This varied collection of ideas reflects the multiple purposes that the party serves. Even the most civic-minded proposal to educate people to share their seats has a bitter aftertaste, since all of these activities are to be undertaken as party campaigns, with the long shadow of the 
party-state looming large. Policing protest, far from being an unrealistic idea by an over-eager student at a brainstorming session, belongs to the ordinary tasks of party members, who are expected to spring into action when they observe the emergence of protest. The author observed this first-hand while standing with a group of party members at a train station in Northern China when an anti-Japanese protest spontaneously formed. The party members decided to have one of them call his party secretary, tell what was going on, and hear instructions. In this case, the party members were told not to participate and observe passively until further notice. Ranging from more innocent initiatives for promoting environmental awareness to more aggressive suggestions for containing citizen protest, the party is successfully channeling people's idealism to serve public purposes as defined by CCP leaders.

The nationwide network of party cells is a formidable instrument in the hand of the government to sway public opinion and to deliberately dominate public discourse. Regularly trained in reciting the orthodox party line on issues ranging from local history to international affairs, the party members' united voice has an excellent chance of prevailing over less coordinated opinions. Moreover, the Organization Department regularly encourages party members to make themselves familiar with the latest technology to amplify the organization's voice. In the early 1990s, party members learned the use of audio-visual technology. ${ }^{47}$ Today, the emphasis is on the Internet. Certain party cells - presumably those with technically more savvy members - in recent years were ordered to become active on Boke, the popular Chinese blog. The minutes of a party cell meeting illustrate how effortless such an operation is for the party:

This party cell has assigned responsibility for the blog Boke to Comrade Zhang, everyone else supports his work. Mr. Zhang told everyone the new Boke password, and strongly encouraged contributions of articles. Strict regulations: During the first two weeks of our new user profile, everyone must contribute six articles; afterwards, everyone has to write one article a week. That way we will gradually perfect our blog and help build the party's encirclement of the blogosphere. ${ }^{48}$

The resulting quite impressive blog is still online. ${ }^{49}$ Similarly, at the outset of 2010, a party general branch ${ }^{50}$ of an educational institution started a blogosphere movement, announcing in its internal work plan that at the end of 2010 "the blogs of all professors belonging to the CCP will be investigated and compared." ${ }^{11}$ Even if the general public denounces bloggers who follow party instructions as the "fifty cent faction," the great number of well-organized party members at the grassroots have 
a good chance to make the party's voice heard in public shouting contests on the Internet. The most effective censors are the ones who not only silence critique, but also manage to make people speak out in favor of the government, using "human wave tactics." Flooding the Internet with government-supportive information is an effective way of controlling public opinion. ${ }^{52}$ The party apparatus facilitates just that.

\section{I.4 MACRO LEVEL: A POLITICAL MAP OF CHINA}

Mainland China does not have liberal blue states and conservative red states. All its provinces are controlled by the CCP, and in that sense they are all dark red. ${ }^{53}$ Without competitive multi-party elections, there are no electoral results to rely on as a clue to individual political preference. Yet in the place of voting patterns, party membership statistics provide valuable information for drawing up a political map of China. As long as we guard against too literal an analogy between voting patterns in a multi-party democracy and membership statistics in a single-party system, we can use membership statistics to distinguish geographical areas where the party's grip is stronger from other areas where the party has less of an effective presence.

\subsubsection{Red vs. Pink Regions}

Until recently, CCP membership statistics were available only in selective and scattered ways. ${ }^{54}$ Mysteriously and temporarily, ${ }^{55}$ in 2011 a compendium of party statistics, compiled by the notoriously opaque CCP Organization Department, appeared on the shelves of China's National Library. It contains unusual detail, such as the number of members who left the party for reasons other than death, and still carried the designation "strictly secret." The collection includes panel data recording provincial-level membership for 11 points in time between 1956 and 2010, mostly corresponding to the years when the plenum of the Party Congress was convened. The data shows distinct and enduring patterns of party presence. This empirical evidence undermines the propaganda message, according to which the party is equally popular, equally strong, and equally present throughout the country's vast national territory.

Table 1.1 ranks China's provinces according to the degree of party penetration. Excluded are 5 million party members who are affiliated with the center; among them are the 2 million party members working for the central state organs, as well as other top elites who are different 
TABLE I.I How red are China's provinces? Party presence in 2010

\begin{tabular}{|c|c|c|c|c|}
\hline & Rank & Province & $\begin{array}{l}\text { Party members } \\
\text { per } 10,000 \text { citizens }\end{array}$ & $\begin{array}{l}\text { Compared to the } \\
\text { national average }\end{array}$ \\
\hline \multirow{10}{*}{$\begin{array}{l}\text { Red } \\
\text { provinces }\end{array}$} & 1 & Beijing & 878 & $+50 \%$ \\
\hline & 2 & Tianjin & 788 & $+34 \%$ \\
\hline & 3 & Shanghai & 761 & $+30 \%$ \\
\hline & 4 & Liaoning & 728 & $+24 \%$ \\
\hline & 5 & Tibet & 696 & $+18 \%$ \\
\hline & 6 & Shandong & 634 & $+8 \%$ \\
\hline & 7 & Sha'anxi & 633 & $+8 \%$ \\
\hline & 8 & Shanxi & 627 & $+7 \%$ \\
\hline & 9 & Hebei & 625 & $+6 \%$ \\
\hline & 10 & Hubei & 624 & $+6 \%$ \\
\hline \multirow{11}{*}{$\begin{array}{l}\text { Light-red } \\
\text { provinces }\end{array}$} & 11 & Zhejiang & 607 & $+3 \%$ \\
\hline & 12 & Xinjiang & 605 & $+3 \%$ \\
\hline & 13 & Qinghai & 602 & $+3 \%$ \\
\hline & 14 & Jiangsu & 597 & $+2 \%$ \\
\hline & 15 & Ningxia & 593 & $+1 \%$ \\
\hline & 16 & Gansu & 590 & $+1 \%$ \\
\hline & 17 & Inner Mong. & 560 & $-5 \%$ \\
\hline & 18 & Jilin & 558 & $-5 \%$ \\
\hline & 19 & Heilongjiang & 554 & $-5 \%$ \\
\hline & 20 & Hunan & 548 & $-7 \%$ \\
\hline & 21 & Chongqing & 548 & $-7 \%$ \\
\hline \multirow{10}{*}{$\begin{array}{l}\text { Pink } \\
\text { provinces }\end{array}$} & 22 & Sichuan & 534 & $-9 \%$ \\
\hline & 23 & Anhui & 530 & $-10 \%$ \\
\hline & 24 & Hainan & 516 & $-12 \%$ \\
\hline & 25 & Henan & 514 & $-12 \%$ \\
\hline & 26 & Fujian & 494 & $-16 \%$ \\
\hline & 27 & Yunnan & 488 & $-17 \%$ \\
\hline & 28 & Guangxi & 456 & $-22 \%$ \\
\hline & 29 & Jiangxi & 446 & $-24 \%$ \\
\hline & 30 & Guizhou & 435 & $-26 \%$ \\
\hline & 31 & Guangdong & 428 & $-27 \%$ \\
\hline
\end{tabular}

Note: The cutoff points between red versus light-red and light-red versus pink provinces are found by deviding the provinces into terciles according to party presence. Sources: CCP members from internal party statistics. ${ }^{56}$ Population data from China Data Online.

from the CCP's rank and file party members at the center of this book. ${ }^{57}$ Even without these elite members, Beijing ranks first, with 878 CCP members per 10,000 citizens in 2010. Guangdong, the economic powerhouse in the South, comes last with only 428 members per 10,000 citizens. The table divides the thirty-one provinces into three equal-sized groups, 


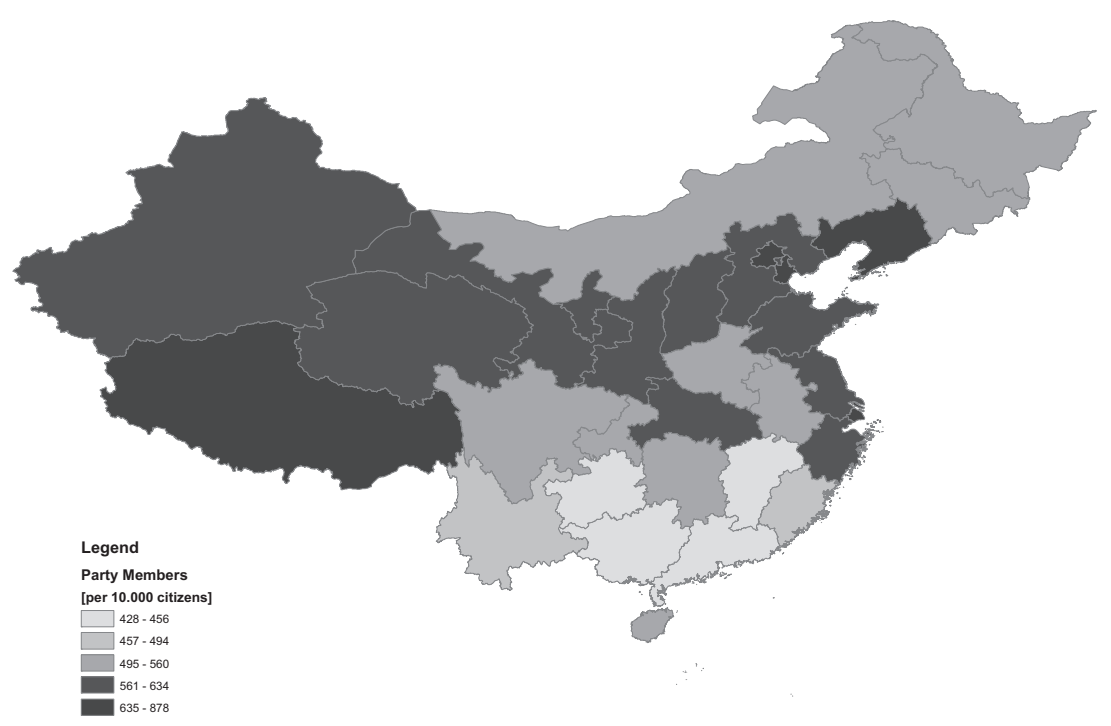

FIGURE I.2 China's red provinces, China's pink provinces (2010)

defining the quantile as China's red provinces, the middle quantile as light red provinces, and the rest pink provinces. Neither economic patterns nor geographic features suggest themselves as easy determinants of party membership patterns. The variation can also not simply be explained in terms of the emerging scholarly narrative of a collectivist North and an individualistic South. ${ }^{58}$ The map in Figure 1.2 illustrates the variation of party membership across China. There are no blue states and red states in China, but some provinces are much redder than others.

As this book demonstrates, the number of party members is crucially significant to understand the varying degree of control that the CCP exercises over different jurisdictions within its realm. Local governments in "red jurisdictions" with high rates of party penetration achieve better results in the domain of China's one-child policy, are more effective tax collectors, and during historical episodes of turmoil have proven more resilient. Local governments in "pink provinces," with a smaller proportion of party members in the population, are less resilient, less effective at collecting taxes, and struggle with the unintended consequences of the one-child policy. Resonating with conjectures that single parties help authoritarian regimes to maintain order, the book shows that the Chinese state is most effective in governing localities with a high proportion of 
party members. To the extent that China's strength is not merely a matter of elite politics in Beijing, but is built on a strong regional base, regime strength originates with the party membership base.

The three micro-dimensions of membership as a screening device, as a tool of social control, and as a mobilization machine in the aggregate translate into important indicators of political control. The degree of party penetration is a meaningful measure across all levels of aggregation, from the village to the province. Just as individuals with CCP affiliation tend to be politically more loyal, a greater presence of party members marks communities that are politically more loyal, either in return for privileges or out of true conviction. The more party members there are in a community, the more people can be mobilized during campaigns and the greater the chances that campaigns reach their goal. Thus, the density of party networks provides valuable clues about state-society relations in local communities. Comparing two Chinese villages, especially if they are similar in other important socio-economic dimensions, a larger number of party members in one village indicates that the CCP's organizational apparatus has more access compared to the other village. Ever since its foundation, the party has meticulously recorded membership statistics as a basis for decision making. For example, during the Sino-Japanese War and the Civil War, the number of party members in a village could be used as an indicator to gauge how much logistical support could be expected; membership statistics were vital for military planning. Today, the number of party members on the ground continues to hold strategic importance for effective governance.

\subsubsection{Interpreting the Political Map of China}

Under the circumstances of a one-party state, in the absence of voting patterns, party strength is a good approximation for capturing the political forces across geographic areas in a nation. The choice of becoming a party member is public and generally irreversible, as party members in their oath specifically promise to dedicate their entire life to the party and as there are no regular procedures for leaving the party. Moreover, the individual knows that there will be direct and personal consequences from joining the party, including privileges as well as loyalty obligations. Much is at stake, with tangible consequences for the individual's everyday life, which is why the membership choice is carefully considered. Even if the choice is not ideologically honest, it certainly is not cheap talk, precisely because of its public, irreversible, and immediately consequential 
nature. In that sense, party membership sends a stronger informational signal than an electoral choice.

While the sheer numerical presence of party members per capita provides a key to China's political geography, it is not a perfect measure. To the extent that the content of party membership varies across space, as a result of distinct, local political cultures, party membership is not entirely comparable across space. For instance, wealthy environments with a strong foreign presence are often said to be more politically liberal; government-critical demonstrations occur more frequently in some provincial capitals than in others, yet this difference does not simply follow the coastal-versus-hinterland divide. ${ }^{59}$ Even without taking into account the varying meaning of party membership across space, the sheer number of CCP members on the ground is a pivotal variable of Chinese politics - even that number already varies greatly. In 2010 the standard error of provincial party penetration is plus/minus 18 percent around that mean, as illustrated by Table 1.1. The eight provinces with high party penetration have 52 percent more party members per 10,000 citizens than the eight provinces with low party penetration. In democratic systems, margins of victory above 5 percent are quite formidable. In the political arithmetics of a Leninist party-state, double-digit differences in party penetration point to significant differences in the degree of control by the party over society.

Moreover, party membership statistics share an important shortcoming with voting patterns: the terms of the deal between the party and its local members are not identical across China, just as voting decisions can be differently motivated in different places. Local party historians, speech writers, and party schools make efforts to standardize the political culture inside the CCP. ${ }^{60}$ Yet in fact, the party members' duties and privileges vary considerably. Informal rules, such as conditions for joining the party and codes of public conduct for party members, differ from place to place. Party members are said to grow more daring the farther they are from Beijing, and the richer they are. ${ }^{61}$ In areas with large minority populations, even the formal rules are adjusted to local conditions. Ethnic politics override standard operating principles of the party. Handbooks for basic-level cadres say that religious believers must not be admitted into the CCP, but places with large minority populations are officially sanctioned exceptions. ${ }^{62}$ Membership statistics tell us nothing about the intensity with which party members hold onto their political identity; they tell us even less about the degree of hostility from nonparty members. Membership statistics of provinces with large ethnic minorities, such as 
Tibet, Qinghai, and Xinjiang, must be taken with a grain of salt. Both the differing content of party identification and the intensity with which people hold partisan beliefs are familiar problems when interpreting electoral outcomes in democracies. All in all, as this book shows, party membership statistics at various levels of spatial resolution provide an important indicator, because the CCP's rank and file are a dependable workforce for the state.

Even if formal rules apply equally to party units across the country, and even if central leaders have been pursuing standardization, regional differences persist and are just as striking as the similarities. Beijing and Shanghai, the political and the economic centers of the country, stand out for unusually high membership. The politically troublesome province of Tibet stands out as well - presumably leaders are engineering party networks as a counter-force to separatist tendencies. If we focus on the pink provinces, there seems to be some truth to the idea that the party's hold decreases with increasing distance from Beijing. ${ }^{63}$ But distance explains only part of the variation and is not a satisfying answer, because it raises the question of why distance hinders the party. For now, it is enough to note that the CCP is a uniform institution only in a superficial sense. Party strength varies considerably across space. For subnational studies of the Chinese polity, this regional variation is fundamentally important.

\subsubsection{Mapping Historical Legacies}

Party membership patterns also provide a particularly parsimonious approach to studying the effect of history on contemporary political outcomes. Taking advantage of the important implications of membership patterns, this book studies "historical legacies" from one particular vantage point, namely its presence in local communities. The more comprehensive, alternative approach would be to define legacies as culture, focusing on the multiple, competing discourses surrounding history, forming political identities in a more or less conscious way, which help to legitimize a regime. Scholars of Latin America have called for such an approach to discern sources of party strength beyond instrumental patronage. ${ }^{64}$ A preeminent example in the study of Asian politics investigates the revolutionary tradition of one key Communist site, demonstrating the central role of historiography in Chinese politics. ${ }^{65}$ Instead, this book defines legacies in a narrow, institutional way. Picking only one variable, the ground-level presence of the party, the book demonstrates that even measuring the 
variable very literally as the sheer number of party members in the population goes a long way to explain political outcomes. One key characteristic of such narrowly defined institutional legacies, setting them apart from cultural legacies, is that they are embedded in organization without necessarily being consciously noted by people acting on them. This mechanical approach brings to light institutional legacies, which are not salient to political debate, of which political actors are not aware, but which nevertheless affect the present state-building outcomes.

Party membership patterns are partly inherited from the past and partly engineered in the present. They shift slowly, as new recruits enter the party. Recruitment in a given jurisdiction results from "demand" from citizens and "supply" from the party. CCP organization departments, well aware of the vital role that CCP members play in the governance of China, are not only closely tracking, but also minutely planning the number and socio-economic composition of the party membership in their jurisdictions. Yearly updated membership development plans, drawn up at all levels of government, indicate strategic goals and tactical measures for party member recruitment. In a top-down fashion, membership application forms, each carrying a unique serial number, are allocated all the hierarchical way down from Beijing to individual work units. ${ }^{66}$ Yet at the same time, there are factors that favor recruitment in precisely the places where the party is already most present: New recruits need recommenders, which are more easily found in places with existing party members. Places with few party members are particularly protective of their status as a small group, where each additional member could challenge the incumbents. By contrast, in places with many party members the incumbents, thanks to their large numbers, are less weary of newcomers. Moreover, party organizers have a lot more information on potential recruits in places where the CCP already has a relatively strong organizational presence. In short, path-dependent forces tie current membership patterns to past membership patterns.

The number of party members in any given jurisdiction is subject to social engineering by party organizers. Strategic considerations explain the extraordinary presence of the party in places such as Beijing, or for that matter Tibet, but they cannot fully account for variation in party presence across China's territory. One would be hard pressed to explain the variation in party membership purely based on strategic reasons that compel the party to cultivate variation of its presence. The party has no full control over recruitment outcomes, so it would be unwise to seek to achieve pre-specified outcomes at all political cost. Quick membership 
expansion is often followed by major party rectification campaigns, as in the 1950s when the party equalized membership between the North and the South: ${ }^{67}$ overly eager admission of new members had attracted insufficiently loyal individuals.

To secure party discipline, party organizers do not make their planning choices blindly, but investigate local party-society relations beforehand. Usually at the end of each year, counties hand up the membership application forms from that year, containing information on the political quality of the candidates in that year. Based on this information, at the start of the subsequent year, prefectures decide on recruitment goals. Counties with a better pool of potential new party members receive a higher quota. In short, the eagerness of politically desirable people to join the party figures into party planners' calculations. Facing trade-offs between quality and quantity, the CCP is likely to require less loyalty and service from members in places where the party is more in need of members. Conversely, in places where the party is flooded with people interested in joining the party, the hurdle for joining will be higher. Yearly recruitment targets reflect the importance that the organization department attaches to recruit new party members, as well as the organization department's assessment as to whether loyal individuals can be identified in a jurisdiction.

\section{I.5 OVERVIEW OF THE ARGUMENT}

After this introduction, a comparative theory chapter argues that single parties are conducive to effective authoritarian regimes around the globe, because they allow states to reach deep into society, especially if they have long, historically grown roots. The following empirical chapters explore this hypothesis through the Chinese case. In Part II of the book, Chapters 3 and 4 study how the CCP's rank and file members contribute to contemporary state-building outcomes. Part III investigates the origins of local party penetration (Chapter 5), and how these origins continue to shape the party (Chapter 6). Covering the Mao era, part 4 refines the findings both about the party effect and about the history effect. Along the way, the book revisits crucial historical episodes, key policy arenas, and the arsenal of governance techniques in modern Chinese state-building (see Table 1.2). Each chapter covers not only a different time period, but also a different domain of state-building in a party state. The chapters deal with the one-child policy, tax collection, averting collapse during the Cultural Revolution, crisis management during the Great Leap Famine, 
TABLE I.2 Chapter-by-chapter roadmap of this book

\begin{tabular}{|c|c|c|c|}
\hline Ch. & Topic & Claim & Method and Evidence \\
\hline \multicolumn{4}{|c|}{ Part I: Autocratic Grassroots Politics } \\
\hline 1 & Introduction & $\begin{array}{l}\text { Party member density is key to China's political } \\
\text { map }\end{array}$ & Descriptive \\
\hline 2 & Theory & $\begin{array}{l}\text { Effects and origins of strong party visible at the } \\
\text { grassroots }\end{array}$ & Literature, deductive argument \\
\hline \multicolumn{4}{|c|}{ Part II: The Party in Contemporary China } \\
\hline 3 & One-child policy & $\begin{array}{l}\text { Party members are essential for smooth policy } \\
\text { implementation }\end{array}$ & Multitask model, fine-grained census data \\
\hline 4 & Tax collection & $\begin{array}{l}\text { Party members enjoy tax privileges, yet are helping } \\
\text { extraction }\end{array}$ & CHIP data, newly available fiscal data \\
\hline \multicolumn{4}{|c|}{ Part III: The Party's Origins } \\
\hline 5 & Pre-1949 warfare & $\begin{array}{l}\text { Japanese occupation shapes membership patterns } \\
\text { of } 1949\end{array}$ & Maps, recruitment data \\
\hline 6 & Persistence & Membership patterns are extremely persistent & Convergence model, original membership data \\
\hline \multicolumn{4}{|c|}{ Part IV: The Party in the Mao Era } \\
\hline 7 & Great Leap Forward & $\begin{array}{l}\text { Still committed to revolution, party strongholds } \\
\text { resisted, suffered less }\end{array}$ & GIS, county-level famine data \\
\hline 8 & Cultural Revolution & $\begin{array}{l}\text { Putting self-interest first, party members contained } \\
\text { turmoil }\end{array}$ & Archival and, other primary documents \\
\hline 9 & Conclusion & $\begin{array}{l}\text { Subnational-historical analysis is key for political } \\
\text { grassroots and parties }\end{array}$ & Summarizing \\
\hline
\end{tabular}


party organization building, and CCP recruitment during wartime. Taken together, the book portrays how state-making and state-remaking have resulted in the structures of one of the world's most resilient party-based authoritarian states.

\subsubsection{Contemporary Effects of a Strong Rank and File}

Chapters 3 and 4 demonstrate that party membership patterns go a long way to explain important governance outcomes today. In the People's Republic of China, the degree of party saturation leads to fundamentally different governance outcomes at the local level. This result might not hold true for all policy areas, especially not for routine implementation and public goods provision by the bureaucracy alone - but it does hold for areas where it is most difficult and most important for the Chinese regime to deploy its authority.

Chapter 3 studies the ambitious one-child policy, which has shown the extraordinary effectiveness of the Chinese party state as a policy enforcer. Based on a modified version of a standard game-theoretical model, it clarifies the distinct functions of the party vs. the bureaucracy. Thanks to newly available, unusually fine-grained census data, it is possible to quantify empirically the distinct impact of bureaucracy and party on the effectiveness of one-child policy implementation. While the presence of government officials was enough to reduce surplus births, only the presence of grassroots party members outside the bureaucracy could contain the detrimental, unintended side effect of uneven sex ratios at birth. Red localities are better at avoiding sex-selective abortions. This illustrates that state strength is not always a result of institutional arrangements at the top-level political center, but in this case is a result of local government effectiveness, achieved by the symbiosis between party and bureaucracy at that grassroots level. In places where the regime party is more present, we see a better-informed government and a more effective implementation of the one-child policy.

Moving from the distinctly Chinese one-child policy to the universal state-building task of tax extraction, Chapter 4 shows that the party's rank and file assist the state in raising resources. The empirical analysis of tax extraction in rural areas demonstrates the quid pro quo between the party and its members. A difference-in-differences approach for the most voluminous taxes, primarily collected in urban areas, allows the establishment of a close relationship between the presence of party members and resource extraction. The chapter is the mirror 
image to the well-established notion that parties function as expensive rent-distributing machines, demonstrating how a successful party collects revenues. Authoritarian parties are costly, but strong parties provide fiscal gains that more than offset such costs. The case of the CCP demonstrates that the provision of patronage can be compatible with a more constructive role of a regime party. In exchange for material benefits to its members, the party not only gets political loyalty, but increases extractive capacity. Places with greater party presence have significantly higher taxation rates, even if party members themselves are more lightly treated. In red areas, the government extracts more taxes than in pink areas, because party networks help to overcome asymmetric information problems usually associated with tax collection in rural areas.

\subsubsection{Historical Origins of a Strong Rank and File}

To explain today's membership patterns, which are so consequential to understand the contemporary reach of the Chinese state, we must go back several generations in history to the formative period of the party. The origins of today's local party organizations fall in the late 1930s, the era of the Sino-Japanese War, when from a situation of near-defeat the CCP returned and established a lasting presence in some parts of China. Chapter 5 analyzes this process. War contingencies are key, especially contingencies during the formative period of the party, namely the time between 1937 and 1945 when large parts of China were under Japanese occupation. Battle fronts in 1937 continue to matter for the enforcement of the one-child policy seventy years later. Even today, the party tends to have a more sizable local presence in places previously occupied by Japan.

The Leninist party apparatus is a strong link that ties governance outcomes in the present to events of the past. Chapter 6, while identifying recent trends for the party to grow fastest in urban areas, points out that party patterns at the time of the Communist takeover go a long way in explaining party patterns today. There is great persistence in the geographic shape of the CCP's power base. To understand why the party has more of an organizational infrastructure in some areas of China, but not in others, one cannot avoid historical investigations. A formal model of party membership growth describes the membership dynamics and allows an empirical test, which demonstrates that legacies of the past do disappear, but only very slowly. 


\subsubsection{Mao Era Effects of a Strong Rank and File}

While this book emphasizes continuities across momentous historical events, the party's history can be divided into three periods, each lasting roughly three decades: the party's ascent until 1949, the Mao era until 1976 , and the era of rising prosperity. Having investigated the contemporary CCP (Part II) and its origins (Part III), the book then turns to the Maoist period in between (Part IV). The Mao era is essential because the traumatic yet idealized experiences of this era are at the core of constitutional debates in China about the nature of the party and the political system writ large. It also provides opportunities to refine the theory and expand its temporal and substantive scope. The goal of including historical cases in particularly tumultuous times is not simply to proliferate examples of the party's rank and file serving state-building interests. In addition, the historical cases bring to light different types of mechanisms, not discernible in the contemporary cases. Most importantly, the Mao era allows us to discover circumstances under which party members work at cross-purposes with the country's top leadership, though ultimately and paradoxically still in the interest of the state.

Chapter 7 studies the Great Leap Forward (1958-1961), along with the ensuing famine. When recognizing the devastating effects of the policies, committed party members were torn between loyalty to the People's Republic and its leader Mao Zedong on the one hand, and their commitment to the cause of the country's destitute peasants, which they had risked their lives for until less than a decade before. Only the most committed party members, found in places where the party was most directly born out of the anti-Japanese struggle, took the great personal risks of dragging their feet, so that people in their surroundings suffered less from the famine disaster. Surely the overall impact of foot-dragging party members was limited. The kind of action they took, by violating party discipline, turned the party into a self-corrective device, prevented deaths, and contributed to state legitimacy.

The height of the Cultural Revolution (1967-1969), when the party hierarchy clashed with Mao Zedong's personal authority and when the People's Republic of China stood at the brink of anarchy, is the topic of the final empirical Chapter 8. Recognizing that one can best assess the defensive capacity of a regime when it is under stress, the chapter demonstrates how a strong local party presence mitigated the impact of the crisis. The chapter provides a thick description of how the party informally continued to function in crisis mode when its hierarchy had collapsed. 
As in the case of the Great Leap Forward, the party did not faithfully implement central commands, which would have been tantamount to selfdestruction, but took a different course that ultimately was in the interest of state-building. For the contemporary period, rank and file party members help state-building, narrowly defined as effective implementation. During the Mao era, this narrow definition was misleading, because of the disjuncture between Mao Zedong's policies and constructive statebuilding goals. Helping implementation under such circumstances hardly qualifies as state-building, whether Mao ignored famine deaths and internal violence or whether he thought of them as worthwhile sacrifices in the interest of building a Communist state. The core hypotheses of this book hold water also for the Mao era: the party's rank and file empowered the state at the local level, also in the past and under different circumstances; and prerevolutionary war contingencies affected important postrevolutionary outcomes.

Each chapter is self-contained, but ultimately the goal of the book is to bridge the different historical layers to provide a comprehensive view of the sources of Chinese state strength. By analyzing the spatial patterns of Chinese state effectiveness, the book illuminates the sources of the People's Republic's effectiveness throughout its realm. It draws attention to the organizational power base inherited from the revolutionary wars, and to a variety of tactics to foster state-building, extractive capacity, and implementation effectiveness of China's party state. From the perspective of authoritarian rulers, the Chinese case demonstrates what a regime party can do for authoritarian governance. 